\title{
1. Swedish roots to Gunnar Myrdal's An American Dilemma (1944)
}

\section{Maribel Morey ${ }^{1}$}

It is often said that when the Swedish economist Gunnar Myrdal arrived in New York City in the autumn of 1938 to direct the Carnegie Corporation's comprehensive study of black Americans (later published as An American Dilemma: The Negro Problem and Modern Democracy), he was approaching an issue of which he had no real experience. After all, the Carnegie Corporation of New York had selected him to direct its study specifically because its president had thought that the Swede could approach the so-called 'Negro problem' from the perspective of a disinterested outsider. In his foreword to the published study, Carnegie Corporation President Frederick P. Keppel described the selection process:

There was no lack of competent scholars in the United States who were deeply interested in the problem and had already devoted themselves to its study, but the whole question had been for nearly a hundred years so charged with emotion that it appeared wise to seek as the responsible head of the undertaking someone who could approach his task with a fresh mind, uninfluenced by traditional attitudes or by earlier conclusions, and it was therefore decided to 'import' a general director. ${ }^{2}$

At the very beginning of his search for a director of the study, Keppel had hoped to enlist Lord Hailey, a British colonial administrator in India who was directing the Carnegie Corporation-sponsored comprehensive survey of white-black relations in colonial Africa (later published as an African Survey). ${ }^{3}$ Keppel shared with some advisers close to Hailey 'his idea for a man of the Hailey type for a study of negro conditions in the United States'. ${ }^{4}$ Unfortunately for Keppel at the time, Hailey was still working on the African project and was thus not available. ${ }^{5}$ During his search, the Carnegie Corporation president repeated to his advisers in the United States and Europe that he was seeking a European director (not an American one), because he was looking for a candidate who would be 
'perfectly free from sentimental and social bias from political prejudice' and would "get away from the point of view that "education" and "school instruction" can be the panacea' to racial differences. ${ }^{6}$ In particular Keppel wanted to find a European director who had experience analysing societal problems comprehensively and drafting public policies to solve them, and who could (with his fresh perspective on the topic) help Americans move away from their belief that education was the key to ameliorating the condition of black Americans. ${ }^{7}$

During the search a trusted American adviser at the Social Science Research Council communicated to Keppel that not all Europeans (just because they were Europeans and not Americans) necessarily would be dispassionate and outside observers to race relations in the United States. Specifically, he noted that Europeans from colonial or fascist regimes or from any other country with majority-minority relations would approach the study of black Americans with earlier conclusions on the topic, or rather, prejudice against black Americans as a minority group. This adviser further suggested to the Carnegie Corporation's president that 'Scandinavian countries [were] perhaps the most free today of such influences'. 8

Heeding this advice and yet still fixed on the idea that a European scholarly statesman who did not 'start from [the] educational end' could provide a fresh perspective on white-black relations in the United States, ${ }^{9}$ Keppel extended an invitation to the Swedish economist and Member of Parliament, Gunnar Myrdal. Another of Keppel's trusted advisers, Beardsley Ruml, had specifically suggested Myrdal in the summer of 1937. Ruml had been the director of John D. Rockefeller Sr.'s Laura Spelman Rockefeller Memorial, which had funded many social science institutes, departments and researchers throughout the United States and Europe in the 1920s. During the 1929-30 academic year, Myrdal had been a recipient of one of its fellowships to study the social sciences throughout the United States, and since then had become one of the Rockefeller organization's star investments in Europe. By 1937 Myrdal was a full professor of economics at Stockholm University, a leading world economist and a significant public policymaker in Sweden. In many ways, Myrdal met Keppel's expectations for a director of the American study. He was a European from a country with no experience of majorityminority relations and he was a scholarly statesman whose work suggested in no way that he would approach the study 'from [the] educational end.' In his letter of invitation to Myrdal later that summer, Keppel concealed his own intent to select a European who would help Americans rethink their approach to white-black relations, but he did 
write that the Swede's lack of experience with majority-minority relations made it possible for him to 'approach the situation with an entirely fresh mind' 10

In return, Myrdal encouraged this image of himself. In his letter of acceptance to Keppel later that autumn, he wrote: 'I agree with you that the study should be undertaken in a wholly objective and dispassionate way. I think also you are right in looking for someone who would approach the situation with [an] entirely fresh mind, a man from a non-imperialistic country with no background of domination of one race over another.' Echoing the Carnegie Corporation president's perception of him as a 'fresh mind' on the topic of black Americans, he continued: 'I quite understand that my special qualification for the task is very much due to the impartiality of a social scientist having acquired no prejudices in the matter in one or the other direction. ${ }^{11}$

Since then, scholars have reproduced this image of a Gunnar Myrdal who had no prior conclusions on black Americans before he became director of the Carnegie Corporation's project in $1938 .{ }^{12}$ As this story goes, he was a Swede with no earlier conclusions on black Americans who spent three years collecting data in the United States from 1938 to 1941. Once Myrdal synthesized this research, these scholars note, he presented and analysed it in the final two-volume study. In An American Dilemma, he concluded that white and black Americans' differences were caused by environmental factors such as discrimination; and that if white Americans changed their behaviour and policies towards black Americans to meet their national egalitarian ideals, black Americans would take on the values, culture and traits of dominant white Americans. ${ }^{13}$

In some ways, this story is true. Myrdal had never studied black Americans in the United States in any detail prior to his appointment as director of the Carnegie Corporation's study, and his thesis in An American Dilemma was accompanied by 1,483 pages of quantitative and qualitative data on black Americans that the author and his staff of researchers collected and synthesized in the United States between 1938 and 1942. But in many more ways this story is untrue. This chapter challenges this narrative by arguing that the projects Gunnar Myrdal and his wife, Alva Reimer Myrdal, undertook in 1930s and early 1940s Sweden informed his approach to the study of black Americans and to his thesis in the final manuscript. Through this lens, Myrdal's An American Dilemma appears not only as a collection of social scientific material about black Americans in the United States, but as an extension of the Myrdals' earlier work in Sweden.

In particular, Myrdal's approach to the study of black Americans and much of his thesis in An American Dilemma grew out of the couple's 
analysis of the so-called Swedish population problem in Kris i befolkningsfrågan [Crisis in the Population Question] (1934). In the 1930s, the couple had been concerned with decreasing fertility rates in their country and proposed population policies to increase the quantity and quality of future generations of children. In their discussion of population quality, the Myrdals explained that the differences between richer and poorer Swedes (like the differences between Jews and non-Jews in Poland and white and black Americans) were caused by environmental, not hereditary or genetic, factors. Because of this, they noted that poor Swedes (like Jews and black Americans) were fully capable of becoming part of their nations' common folk, or rather, the national social body.

As director of the American study, Gunnar Myrdal started his research on black Americans from an environmentalist perspective. In the book that resulted he presented the data that he and his associates had collected on the social and institutional barriers that, in his view, kept black Americans distinct from the rest of the population. As in Crisis in the Population Question, he argued in the American manuscript that these barriers could and should be removed. If black Americans' environmental differences with white Americans were erased, they could become part of the nation's common folk.

White Americans could facilitate this process of assimilation and integration, Myrdal continued, by changing their behaviour and public policies to reflect their national egalitarian ideals. This part of his thesis grew out of the couple's pro-American propaganda book, Kontakt med Amerika [Contact with America], which they wrote in 1940 Stockholm during a hiatus from the American project. In this book, the couple tried to rally support for the United States in Sweden by showing their fellow citizens that (unlike Germans in their treatment of Jews) Americans were morally distressed about their unequal treatment of black Americans. They argued that Americans held national egalitarian ideals ('the American Creed') that made them want to correct their discriminatory behaviour toward black Americans, and because of this, that Americans deserved Swedes' support during the war. In An American Dilemma, Myrdal used the concept of the American Creed to explain to his American readers how they could go about achieving black Americans' assimilation and integration into the dominant white American culture. The concept matured as wartime propaganda for the United States in Sweden became, in this later book, a crucial part of Myrdal's thesis on how to solve the so-called 'Negro problem'. 
As much as the Carnegie Corporation might have wanted to imagine the director of their comprehensive study of black Americans as a tabula rasa whose analysis grew out of his observations in the United States (and as much as the director himself and future scholars encouraged this image), ${ }^{14}$ Myrdal's approach to the study of black Americans and his thesis in the final manuscript were informed by his and Alva Myrdal's work in 1930s and early 1940s Sweden. Far from being a work for and about Americans, An American Dilemma was an extension of the couple's earlier work and, equally so, an extension of 1930s and early 1940 s discussions of the population problem and wartime allegiance in Sweden.

\section{CRISIS IN THE POPULATION QUESTION}

In 1929, Alva and Gunnar Myrdal both received Rockefeller fellowships to spend the 1929-30 academic year reading at the British Museum and traveling throughout the United States meeting sociologists, psychologists and economists at various American universities. After the Great War, the Rockefellers' Laura Spelman Rockefeller Memorial had initiated these fellowships with hopes of helping young European researchers such as the Myrdals gain exposure to the newly growing fields of the applied social sciences in the United States. The Rockefeller Foundation took over the memorial's funding of the social sciences when it subsumed the smaller organization in 1929, and like the memorial, the foundation expected that these young and promising fellows would (with its continued financial backing) strengthen these fields in their home countries. By strengthening social scientific research in Europe, these philanthropic managers expected that they would be helping governments stabilize their populations and thus prevent a second world war. ${ }^{15}$

Gunnar Myrdal was a bright young economist who had published a few books on economic theory. ${ }^{16}$ Alva Reimer Myrdal was a recent university graduate interested in child psychology. They spent the year poring through scholarship, meeting social researchers throughout the United States and witnessing the effects of the stock market crash of 1929. This combination of experiences made Gunnar less interested in economic theory and much more in applied economics. From her end, Alva saw this as an opportunity to co-author with Gunnar. ${ }^{17}$

When the Myrdals returned to Stockholm in 1931, Gunnar continued work at Stockholm University and within a year became a professor of 
political economics and financial science at the university. ${ }^{18} \mathrm{He}$ also became a member of the committee directing research at the Rockefellerfunded Institute for the Social Sciences and Alva became director of the Institute for Social Pedagogy. ${ }^{19}$ During these years, they both became involved with the Social Democratic Party and preached the importance of applying modern social scientific research to public policy making. Their first joint attempt in this vein was the publication in 1934 of Crisis in the Population Question. Gunnar wrote the 'demographic and economic aspects' and Alva the 'treatment of social policy'. ${ }^{20}$

In Crisis, the Myrdals engaged with the ongoing debates on decreasing fertility rates in Europe and argued that they had a policy answer to this problem in Sweden. ${ }^{21}$ After the First World War, several belligerent countries in Europe had become worried that they would suffer steep population declines since they had lost so many young men during the war. They believed that these men's deaths signalled a decrease in the quantity and quality of the nation's population and that this left the nation at a disadvantage with a smaller and weaker social corpus. ${ }^{22}$ Some perceived that this was disastrous for the nation's sense of identity, while others (who assumed that more workers meant a stronger economy) perceived the nation's compressed social body as a threat to the nation's economy. ${ }^{23}$

Although Sweden had remained neutral during the war, its people engaged in this interwar continental conversation on population. ${ }^{24}$ In Crisis, the Myrdals claimed that Swedes were right to fear decreased fertility rates and explained that these declining rates could be reversed. The couple's book began with a description of economic theory, and here, Gunnar made clear that he was opposing his theory to that of the English scholar Thomas Robert Malthus. ${ }^{25}$ In the late eighteenth and early nineteenth centuries, Myrdal explained, Malthus had argued that human beings confronted limited resources on earth, so population growth threatened the existing population's quality of life. While he had been hesitant to propose contraception, the Englishman had suggested that people should marry later and try to have fewer children than they were currently producing. ${ }^{26}$ The generation of neo-Malthusians who followed also warned that populations were becoming too numerous for the limited resources that humans could produce. But unlike Malthus, they were much more vocal about condoning and promoting the use of contraception in an effort to limit fertility rates. Among these neoMalthusians was the famous American birth control advocate Margaret Sanger whose work had spread across both continents. ${ }^{27}$

By contrast to scholars and advocates who believed that human beings needed to decrease fertility rates in order to maintain their quality of life, 
Myrdal declared that a balanced population size was more beneficial for these purposes. ${ }^{28}$ In Crisis in the Population Question, he and his wife argued that crafting a balanced population that maintained a sufficient number of productive citizens to support the unproductive citizens (including children and the elderly) was more important than limiting the total population numbers. A balanced population, they said, would secure a sufficient number of working citizens to support the non-working ones in any national economy.

In the case of Sweden, the Myrdals explained that neo-Malthusians had been effective in promoting delayed marriages and contraception and that the country then suffered alarmingly low fertility rates. The low number of young Swedes not only threatened the country's ability to support the future aging population, but it threatened Swedes' existence as a nation. ${ }^{29}$ If Swedes continued to reproduce in such low numbers, the authors explained, then other populations could immigrate into Sweden and overwhelm and threaten the dwindling native Swedish population. ${ }^{30}$ Continued lowered reproductive rates, they wrote, "would signify the race's degeneration and mean "racial suicide." If the population size is reduced, the land would be flooded by immigrants of alien groups with high fertility rates. With their stronger numbers, they could take over and transform our precious cultural heritage. ${ }^{31}$ The Myrdals here delineated a distinction between immigrants and native Swedes in order to explain why encouraging immigration to the country was not an appropriate way of inflating the Swedish population. Instead, they suggested, Swedes should increase their population size by increasing their own fertility rates.

The Myrdals were aware that young Swedish couples would not hearken easily to this message. At the turn of the century, economic conditions for the Swedish masses had been so dire that 23 per cent of the population had emigrated..$^{32}$ Against this backdrop, the country's transformation into a modern, urban and industrial society in the 1920s and early 1930s was all the more dramatic for its population. Many young Swedes were moving from the countryside to urban centres and did not want to give up the modern lives that they were establishing for themselves. Swedish women still wanted to work, and when they married, they (like their husbands) were unwilling to make the financial and lifestyle sacrifices that having children represented. If Sweden wanted to increase its fertility rates, the Myrdals asserted, it would need to keep in mind this kind of young urban and modern couple and create policies that limited the burdens of childrearing. ${ }^{33}$

Potential young parents, they advised, neither should be forced into parenthood nor burdened with new financial responsibilities that 
decreased their quality of life. In this vein, the Myrdals suggested that the state should promote the free exchange and use of contraception, ensure mothers' ability to retain their employment outside their homes and provide services that covered the main costs associated with parenting. ${ }^{34}$ Specifically they proposed that the Swedish state should cover living subsidies for families with children: free public nurseries, baby cribs and kindergartens; free health services and free school lunch for all children; price reductions for necessary food items for children living at home; all costs for school materials (including school buildings, books and transportation to and from the school) and education stipends. ${ }^{35}$

The Myrdals noted that population quality not only concerned the quality of parents' lives, but the quality of the children they brought into the world. These state benefits would ensure that Sweden's future children would be more educated and healthier than previous generations. In other words, the way to improve the quality and quantity of future generations of Swedes was to create public policies that offered resources to parents and children alike.

In proposing such policies, the Myrdals were explicitly distinguishing themselves from other population experts in Germany, Italy and France, whom they thought were merely interested in increasing the population size irrespective of how childbearing and childrearing affected couples' quality of life. ${ }^{36}$ In discussing the quality of future generations of Swedes, however, the Myrdals did not completely distinguish themselves from these continental population experts.

For improving population quality, for example, the Myrdals considered the importance of hereditary characteristics and genetics, but advocated a guarded approach to such considerations. The 'quality problem can be tackled thus, with studying individual differences in the population and finding to which degree those differences are hereditary or conditioned by the environment ... In the case of differences conditioned by the environment, one can of course change the population's quality by (in different ways) changing the environmental conditions for certain individuals. ${ }^{37}$ Most differences among individuals within a national community, the Myrdals noted, were caused by the environment, and thus could be remedied by changing the population's surroundings (such as improving living, health and education standards).

However, some differences could not be 'remedied'; when it came to the mentally ill and mentally deficient, the Myrdals advocated sterilization. They noted that race biologists and social pedagogues each had different reasons for sterilizing these individuals, and concluded that they sided with the latter's reasons. The Myrdals observed that 'hereditary biologists have already made interesting and practically meaningful 
contributions and one has reason to expect more in the future', but explained that they were not ready to say that mental illness and mental deficiencies were definitely passed on from parent to child. ${ }^{38}$ Instead, the couple concluded that individuals with such illnesses and deficiencies should be sterilized because (as social pedagogues argued) their abilities to parent were limited. ${ }^{39}$ In 'Eugenics and the Welfare State in Sweden', Alberto Spektorowski and Elisabet Mizrachi note that other Swedes at the time supported sterilization on 'eugenic, social, humanitarian and criminal' grounds, with the social grounds entailing 'first and foremost the situation where persons are psychologically or physically inferior to such a degree that they cannot, or are not suited to care for their children'. ${ }^{40}$ The Myrdals were thus part and parcel of 1920s and 1930s socialist eugenics politics in Europe and, like some, supported the sterilization of the mentally ill and deficient on 'social grounds' ${ }^{41}$

In the rest of their discussion of population quality in Crisis in the Population Question, the Myrdals returned to the environmental factors that created quality differentials within the nation's population and argued that the state should go about improving the quality and quantity of the population by improving and equalizing Swedes' environments. To this point, the Myrdals made clear that 'social group differences' were irrelevant in discussions of population quality. Citing the differences between poorer and richer Swedes, they argued that class characteristics such as intelligence, affluence and success were caused by the environment, and thus were not hereditary or genetic. In the case of intelligence, they referred to a contemporary study of schoolchildren in England that showed that children of academics, doctors, lawyers and writers scored higher than children of factory workers on intelligence tests, and claimed that these differences resulted from differences in their upbringing. ${ }^{42}$ '[T]hose children of intellectual workers have, from their very early ages, more intellectual training at home than is often granted the children of heavy work or wholesale traders' ${ }^{43}$ The intelligence gap between poorer and more affluent children in England or in Sweden could be bridged if children were offered similar childhood benefits.

When it came to the upper classes' multi-generational affluence and success, the Myrdals noted that 'the higher classes's children receive better upbringing, better education, they are accustomed to significant social security and know how to make use of personal connections'. ${ }^{44}$ That is, environmental factors such as childrearing, education and friendships - not genetics - led the higher classes to perform better on intelligence exams and to be more successful and affluent than the lower classes. To further substantiate their claims, the Myrdals noted that 'researchers do not support the hypothesis of the existence of socially 
significant character differences between social classes that are of hereditary quality'. ${ }^{45}$ Moreover, they explained, 'a social group is actually not (like an individual) a naturally given biological unit; but rather, created by social and institutional factors established and accumulated by highly different individuals' ${ }^{46}$ If only the social and institutional factors that maintained poor and lower class Swedes' inferiority were erased, then these Swedes could achieve the same health and intelligence standards as the rest of the population.

As an extension of their analysis of the environmental factors leading to differences in population quality among socio-economic classes, the Myrdals engaged with contemporary scholarship on race. They explained that racial distinctions, like class differences, were 'social group differences' caused by the environment, ${ }^{47}$ and that hereditary and genetic arguments had no place in discussions of population quality among these groups. They wrote: 'One should take note that the modern, empirical, and nonspeculatively working social psychology is led to follow quite the opposite working hypothesis, namely that - when it comes to large social groups - differences at the average level of different mental, inherited abilities even between completely separate races, plays relatively little role ... No social group possesses that uniformity, that biological high or low rank, which one sometimes in one's national improvement efforts, wanted to assume. ${ }^{48}$

In particular, the Myrdals noted that their analysis of social group differences applied in other corners of the world: 'If blacks in America or Jews in Poland display certain average racial characteristics in their actions, by that it should be explained, that since childhood they had been branded, treated and had to react just as blacks in America or Jews in Poland. ${ }^{49}$ Just as social and institutional environments were to blame for creating poor and lower class Swedes' differences, so too were these environmental factors to blame for creating black Americans' and Jews' own differences in their respective societies. If black Americans and Jews in Poland were not raised and treated as black Americans or Jews, the Myrdals asserted, they could assimilate and achieve the same standards of their nations' common folk.

It is important to note that in Crisis, the Myrdals discussed black Americans in the context of social group differences, rather than in their discussion of immigrants to Sweden. In other words, they perceived that black Americans belonged in the American folk in a way that 'immigrants of alien groups' did not belong within the national community in Sweden. They argued that the differences between white and black Americans (like the differences between richer and poorer Swedes and 
Jews and non-Jews in Poland, but unlike those between immigrants and natives of Sweden) could be erased to create a common nation.

In this 1934 book, the Myrdals clearly accepted the existence of an ethnically and racially diverse folk in the United States. This was distinguishable from their image of the Swedish nation, which they described as a homogeneous group distinguished only by class differences and free of the other subordinate social group dynamics present in other parts of the world. In their discussion of Sweden's national community in Crisis in the Population Question, the couple did not mention Jews or indigenous Sami who lived in Sweden, and these were visible minorities. ${ }^{50}$ From reading the Myrdals' work, it seems possible that the couple was more attuned to class, rather than ethnic or religious, distinctions in Sweden. Another reason could be that, born and raised as Swedes, the Myrdals had a stricter definition of who belonged in Sweden and who was legitimately Swedish than they did of who belonged in other countries and what defined those subordinate groups as legitimate members of those national communities.

\section{CRISIS IN THE POPULATION QUESTION AND MYRDAL'S APPROACH TO THE STUDY OF BLACK AMERICANS}

After the publication of Crisis in the Population Question, Gunnar and Alva Myrdal became leading figures in the Swedish Social Democratic Party and particularly in the country's discussion of the population problem, which came to the fore in 1930 s Sweden. ${ }^{51}$ The party capitalized on the public debate that was created in the wake of the couple's book to promote welfare policies and in the process the Myrdals became equated with the Social Democratic Party and its social policies. ${ }^{52}$ In the mid 1930s, Gunnar was elected to the upper house of parliament and became a member of the Royal Population Commission. As for Alva, she was chair of the Swedish Professional Women's Association, secretary of the government commission on the right of married women to work outside the home and a member of the Social Democratic Women's Association. ${ }^{53}$ At the ages of 39 and 35 respectively, Gunnar and Alva were creating solid professional lives for themselves in Stockholm. Even more, they had three young children and a newly constructed home in the suburbs. Just then the Carnegie Corporation of New York came along with an offer to tempt the Myrdals to leave their settled lives behind - at least temporarily. 
In the autumn of 1937 Gunnar accepted the Carnegie Corporation's offer to direct a comprehensive study of black Americans, and within months the Myrdals formalized their leaves of absence from their academic and political posts. In early September of 1938 they boarded a ship to New York, accompanied by their three children, two nannies and one of Gunnar's associates, Richard Sterner, and his wife. ${ }^{54}$

During the first two months in the United States, Myrdal and Sterner travelled throughout the South to talk with black and white Americans alike. ${ }^{55}$ Two months later Myrdal sent Carnegie Corporation President Frederick P. Keppel a 63-page letter outlining exactly the kind of data he needed to collect. ${ }^{56}$ Much as in Crisis, Myrdal explained to Keppel that he believed that the differences between white and black Americans were caused by environmental (not hereditary or genetic) factors. In particular, he told the president, he would not be looking for the supposed 'inborn qualities of the American Negro'. ${ }^{57}$ 'If my impression is correct', he wrote, 'that the inborn physical and mental (intellectual and moral) qualities of the American Negro, or, rather, the differences with regard to these qualities between Negroes and other groups in the American population, are not in themselves of great significance in the social problem, no intensive studies should be made in these fields' ${ }^{58}$ Instead he was hoping to analyse topics of 'importance to social programs of immediate actuality and to changes actually under way in the relations between the races, some of them bringing forth a more harmonious modus vivendi, but some intensifying the several dilemmas confronting American culture because of the presence of the Negro'.${ }^{59}$ He made it clear to Keppel that he thought that social and institutional factors - not heredity or genetics - created the differences between white and black Americans, and that these were the factors that he would investigate.

For the next year, Myrdal travelled around the country and, alongside Sterner, managed his team of over 70 American researchers. ${ }^{60}$ They all worked to ascertain "in some detail the actual demographic, economic, education, social and political status of the Negro population in the United States'. They observed 'the several dilemmas confronting Negro groups and the American culture at large' and investigated 'particularly the Negro-white race relations'. Last, they scrutinized 'the induced changes (or the interferences) in the process of change and adjustment, represented by legislative programs, educational work, interracial efforts, concerted action by Negro groups, etc. ${ }^{61}$ In other words, they studied what they believed was every possible environmental barrier to black Americans' assimilation and integration in the dominant white population. 
After collecting this data, Gunnar Myrdal planned to write his policy analysis and complete the Carnegie Corporation's study of black Americans by October of 1940. But in April of the same year, Germany invaded Denmark and Norway. Myrdal was still collecting reports from his researchers and had not yet begun the manuscript. However, he explained to the Carnegie Corporation's president, it was his duty to return to help his fellow countrymen fight a probable Third Reich invasion and to share their fate. Richard Sterner and his wife could stay, he explained, but he and Alva were prominent Swedes and their country needed them.

The corporation agreed to Myrdal's decision and made plans for an American sociologist in Chicago, Samuel Stouffer, to manage the reports that remained to be submitted during his absence. Less than a year later, Myrdal returned to write the final manuscript of this study. In $A n$ American Dilemma: The Negro Problem and Modern Democracy, Myrdal elaborated on the discussion of white and black Americans that he had initiated in Crisis in the Population Question. As in that earlier book, he again explained that the environmental factors that caused the differences between white and black Americans should be removed so that black Americans could assimilate and integrate into the dominant white population.

\section{CRISIS IN THE POPULATION QUESTION AND MYRDAL'S THESIS IN AN AMERICAN DILEMMA}

In the two volumes and 1,483 pages that made up An American Dilemma, Myrdal presented a summary of the environmental factors that kept black Americans distinct from white Americans, based on information that he and his staff had collected during the previous years. ${ }^{62}$ He wrote chapters on economic inequality, economic discrimination, political inequality, inequality of justice and social inequality, ${ }^{63}$ alongside chapters on black American families, churches, schools and voluntary associations - all factors he believed were significant in creating differences between white and black Americans. ${ }^{64}$ Myrdal argued that these environmental distinctions should be erased so that black Americans could become part of the dominant American population occupied by whites. As in Crisis in the Population Question, he assumed that the dominant group defined the identity of the nation and that it was in the interest of the subordinate social groups to become part of this dominant group. In Crisis, he and Alva had presumed that it was in the interest of poorer Swedes to receive state benefits and attain the standards of richer Swedes. Similarly he 
noted here that he and his associates 'assume that it is the advantage of American Negroes as individuals and as a group to become assimilated into American culture, to acquire the traits held in esteem by the dominant white Americans'. ${ }^{65}$ Once these environmental barriers to black Americans' assimilation and integration were erased, Myrdal imagined that black Americans could and would become just like white Americans.

In the second volume of An American Dilemma, he explained:

As more Negroes become educated and urbanized, it may be expected that they will lose their distinctive cultural traits and take over the dominant American patterns ... As the trend proceeds, and as there emerges a class of Negroes which is recognized by whites to have the same cultural traits as themselves, the Negro will be thought to be less 'peculiar' than he is now. Recognition of increased cultural similarity is not unimportant in the general attitude of whites toward Negroes. Thus cultural assimilation plays a role in the general circular process determining the Negro's status in America. ${ }^{66}$

As white Americans continued to dismantle the social and institutional barriers that made black Americans distinct from them, Myrdal expected that black Americans would assimilate, integrate and become part of the common white American population.

Scholars have long criticized this part of Myrdal's thesis and wondered why Myrdal thought that racial equality required black Americans to appropriate the traits, habits and culture of white Americans. ${ }^{67}$ They have noted that Myrdal's argument for racial equality in the United States downplayed the importance and value of black culture and institutions by calling for their destruction, and in the process, required black Americans to make too great a sacrifice in order to gain their rightful equal status in American life. In other words, these critics have found disconcerting Myrdal's claim that black Americans' due equal status in American society should depend on their ability (and willingness) to abandon their own culture and institutions and act, live and speak as mainstream white Americans.

To understand why Gunnar Myrdal made this argument it is crucial to place this text alongside his and Alva Myrdal's presentation of population quality in Crisis in the Population Question. In particular, it becomes clear that his vision of racial equality in An American Dilemma was rooted in the couple's analysis of social group differences in 1930s Sweden. In Crisis, as in An American Dilemma, Gunnar Myrdal assumed that a nation was made up of a common, almost homogeneous people, and on this point he did not depart from the assumptions of race biologists. $^{68}$ In both works Myrdal assumed that everyone in a nation should dress, act and live similarly. However, unlike race biologists who 
deemed that certain social groups had hereditary or genetic characteristics that prevented them from achieving the norms of the dominant group, Gunnar Myrdal explained in both works that these differences between groups were caused by the environment and that social group members (whether poor Swedes, black Americans or Jews in Poland) could change and become like the dominant mainstream in their countries. He made this argument in direct opposition to German racial theorists who, since 1933, had been ostracizing Jews on the grounds that this group had certain hereditary and genetic characteristics that made them incompatible with the country's national community.

\section{CONTACT WITH AMERICA (1941)}

While Myrdal's approach to the study of black Americans and his argument in the final manuscript of An American Dilemma was clearly informed by his and Alva Myrdal's analysis of population quality in 1930s Sweden, the second part of his argument, that white Americans could go about breaking down these environmental barriers by changing their behaviour and policies toward black Americans to reflect their egalitarian values, was developed in a second project that the Myrdals co-authored before Gunnar Myrdal wrote the American manuscript.

As already noted, the Myrdals left behind their unfinished study of black Americans in the spring of 1940 in order to return to Sweden and await their country's fate during the Second World War. By then, Gunnar Myrdal already had suggested to his staff and his employers at the Carnegie Corporation that he would like to frame the American project around the 'American state religion' of justice, equality, and freedom. However, during their time in Sweden, the couple developed his thoughts on the 'American state religion' beyond that of an intra-staff memorandum and termed it 'the American Creed.' It is also here where we can come to appreciate the wartime dimensions of Gunnar Myrdal's mention of the American Creed in An American Dilemma.

Historian Yvonne Hirdman writes that the Myrdals crossed the Atlantic 'on a cargo steamer loaded with arms, arriving in Petsamo (northern Finland), and flying from there to Sweden with two little girls and an irate, taciturn son who had wanted to remain in New York' ${ }^{69}$ The family was back in Stockholm by early June of 1940 .

Contrary to their expectations, Gunnar and Alva were not offered wartime tasks within the Swedish government. ${ }^{70}$ This, of course, bruised their egos, but they quickly created wartime work for themselves in the form they knew best. As in the early 1930s, Alva and Gunnar Myrdal 
came together to co-author a book. This time it was a 373-page defence and glowing description of the United States, Contact with America, published in $1941 .^{71}$

The idea for the project came once the couple perceived that their fellow countrymen were succumbing to the pressures of the Third Reich. After Alva arrived in Stockholm, she wrote to an American friend that she saw some colleagues and friends turn into outright Nazis and wondered to another Swedish friend how their country could have changed so much. The Sweden that she had left had been a modern, democratic and forward-thinking country that had served as a model for other democracies such as the United States, but the one she returned to in 1940 was conservative, traditional and tolerant of the Third Reich. ${ }^{72}$

In writing Contact with America, the Myrdals aimed to garner support for the United States in Sweden. In the summer of 1940, the United States was already informally engaged in the Second World War and appeared likely to soon become a formal belligerent. ${ }^{73}$ The couple wanted to make clear to fellow Swedes that there was an inherent difference between modern-day Germans and Americans and that the latter was worthy of Swedes' allegiance during the war. They set out to disprove stereotypes about the United States that their fellow countrymen seemed to hold; in particular, they sought to explain that the US was not just a heterogeneous group of people who treated racial minorities (particularly black Americans) as cruelly as Germans treated Jews. Rather the United States (like Sweden) was a common folk united by egalitarian national ideals.

America, they acknowledged, 'is more heterogeneous' than any other country, so it 'takes a long time and through lively studies before one discovers that which is shared and stable [there]'. ${ }^{74}$ However, they noted, the 'secret is that America, more than any other land in the Western world, large or small, has the most homogeneous, firmly and clearly formulated, vividly living system of expressed ideals for human social life ... Each American has had them stamped in his mind'. This, they explained, was the 'American creed' that bridged the American people together. ${ }^{75}$ Here, the Myrdals developd the concept that was to frame the central thesis of An American Dilemma: the American Creed.

Every American, the couple explained, shared the belief that '[a]ll individuals have the same rights in relation to each other and before the state, independent of race, religion, and standing. Around each individual, in whatever condition he lives, stands therefore an aura of clear rights which even the state must respect. ${ }^{76}$ These were, according to the Myrdals, shared egalitarian ideals to which Swedes could relate, and that were lacking among the German people. 
The authors conceded that Americans, like Germans, treated racial minorities brutally. However, they noted that Americans, unlike Germans, were eager to correct their discriminatory behaviour in order to live up to their egalitarian ideals. '[N]o people on earth are (or ever were) so passionately interested in finding and crying out their own deficiencies as Americans', they wrote. ${ }^{77}$ Indeed, Gunnar Myrdal mentioned he had been asked to research black Americans in the United States and he very much doubted that Germany would ever have invited a foreign researcher to analyse 'the country's most difficult race problem - the Jewish question'. ${ }^{78}$

Because of their adherence to this creed, Americans distinguished themselves from Germans. Gunnar reported: 'I often would ask [Americans] how they could criticize so much the treatment of Jews in Germany, while their own Negroes and so often many of their poor whites did not have it much better. The answer was: 'But we do not say that what happens is right! That is the difference between America and Germany, that here that goes against our ideals. ${ }^{79}$ Moreover this gap between actions and ideals caused Americans emotional distress. According to the Myrdals, 'The Negro problem, like all the other difficult social problems, is mainly a problem in Americans' own hearts.' 80 In other words, the American people were bound together by egalitarian ideals and when white Americans treated black Americans unequally, they felt ashamed. Americans, unlike Germans, aspired to be a more egalitarian people.

In comparing these two countries, the couple hoped to convince readers that Sweden was more akin to the United States than to Germany. In Gunnar's words:

One of those who writes this has had, for the last two years, the assignment of becoming an expert exactly on America's social deficiencies and he knows more about those imperfections than maybe anyone else who writes in the Swedish language. He knows quite well how much more evil, injustice and shortcomings still remain in America compared to Sweden. But he has also learned how much more there is of goodness, justice, and extraordinary power. ${ }^{81}$

For this reason, they believed, the United States, despite its unequal treatment of black Americans, was worthy of Sweden's support. The American Creed was at the very heart of the Myrdals' distinction between Germany and the United States in Contact with America. In these national egalitarian ideals, they found a straightforward and clear way to distinguish in the minds of Swedes the United States's treatment of black Americans from Germany's treatment of Jews. 
Just as this Swedish book went to press in the first weeks of 1941, Gunnar Myrdal made his way back to the United States to complete his study of black Americans. Alva Myrdal and their three children stayed in Sweden, while he travelled to New York - via Moscow, the TransSiberian Railway, Vladivostok, Japan, Honolulu, San Francisco, and Chicago - arriving at the Carnegie Corporation offices in Manhattan three months after he had left Stockholm. ${ }^{82}$ Alva Myrdal joined him six months later via England and Portugal. From the autumn of 1941 to September 1942, the couple secluded themselves in Princeton, New Jersey, where Gunnar Myrdal wrote the final manuscript that became $A n$ American Dilemma: The Negro Problem and Modern Democracy. Due to paper shortages in the United States during the Second World War it was not published until two years later, in 1944.

\section{CONTACT WITH AMERICA AND MYRDAL'S THESIS IN AN AMERICAN DILEMMA}

Before writing An American Dilemma, Gunnar Myrdal already knew that he wanted to argue that the social and institutional barriers to black Americans' assimilation and integration should be removed. As in Crisis, he also assumed that black Americans should be willing to shed their own identities as black Americans in order to take on the characteristics that white Americans valued.

The parallels between Myrdal's description of social group differences in Crisis, his approach to the study of black Americans, and his thesis in An American Dilemma all suggest that he remained firm in his and Alva Myrdal's conviction that black Americans could and should assimilate and integrate into dominant white American life. However, in Crisis he had not needed to explain how one would go about creating the political willpower to transform American society in that way. On this point, his and Alva Myrdal's continued work on the concept of the American Creed in Stockholm just a few months earlier became useful. In $A n$ American Dilemma, he explained to his American readers that their American Creed could guide them toward achieving this vision of racial equality.

In An American Dilemma, as in Contact with America, Gunnar described the so-called 'Negro problem' as 'a problem in the heart of the American. It is there that the interracial tension has its focus. It is there that the decisive struggle goes on'. He continued in the American book: 'Though our study includes economic, social, and political race relations, at bottom our problem is the moral dilemma of the American - the 
conflict between his moral valuations on various levels of consciousness and generality.' 83

In both books, Myrdal asserted that it was this national egalitarian value, the American Creed, that made white Americans feel consciencestricken that black Americans were not part of the dominant common folk. He wrote in An American Dilemma: 'From the point of view of the American Creed the status accorded the Negro in America represents nothing more and nothing less than a century-long lag of public morals.' Noting as he and Alva had in Contact, he explained that white Americans' treatment of black Americans fell short of these egalitarian ideals. ${ }^{84}$ In the American study, Myrdal used the concept of the American Creed to show American readers how they could assimilate and integrate black Americans into the national community:

In principle the Negro problem was settled long ago; in practice the solution is not effectuated. The Negro in America has not yet been given the elemental civil and political rights of formal democracy, including a fair opportunity to earn his living, upon which a general accord was already won when the American Creed was first taking form. And this anachronism constitutes the contemporary 'problem' both to Negroes and to whites. If those rights were respected ... there would no longer be a Negro problem. ${ }^{85}$

If white Americans aligned their behaviour and policies toward black Americans to meet their American Creed, they could assimilate and integrate this subordinate social group into the national community; and in the process solve their so-called 'Negro problem'.

In the manuscript of An American Dilemma, Myrdal transplanted the discussion of the American Creed that he and Alva Myrdal had developed in Contact with America. The American manuscript not only mentioned this creed to distinguish Americans' unequal but guilt-ridden treatment of black Americans from Germans' own genocidal treatment of Jews, but to show Americans how they could differentiate themselves from Germans in practice. The United States, unlike Germany, could prove itself capable of maintaining a common national folk by assimilating and integrating, not eradicating, subordinate social groups.

\section{CONCLUSION}

Gunnar Myrdal was hardly a blank slate when he became the director of the Carnegie study in 1938 nor was his thesis in the final manuscript of the study solely the result of the data he and his team of researchers collected on black Americans in the United States between 1938 and 
1941. Instead, his and Alva Myrdal's analysis of population quality in mid-1930s Sweden informed his approach, as did the concept of the American Creed, which was the centrepiece of the propagandistic book that the couple wrote in early 1940s Sweden. Seen from this perspective, it becomes clearer why Gunnar Myrdal argued what he did in $A n$ American Dilemma, and specifically, how his theory of racial equality in this 1944 book related to his and his wife's writings on social group differences and wartime allegiance in Sweden.

Read today, some aspects of Myrdal's theory of racial equality in An American Dilemma seem to be part of a bygone era. In the 1930s the couple had been concerned with crafting a population policy that could integrate and assimilate social groups, instead of excluding or annihilating them as German racial theorists proposed. Speaking broadly, it is fair to say that Americans and Swedes today largely would take this part of Myrdal's argument in An American Dilemma for granted: of course subordinate social groups such as black Americans can assimilate and integrate into dominant groups. From this perspective, the vast majority of contemporary Swedes and Americans might consider his theory of racial equality, and more broadly, his theory of social group equality, as commonsensical or even irrelevant to contemporary discussions of majority-minority relations.

And yet, the two other strands of Myrdal's thesis in An American Dilemma seem all too relevant. Like many contemporaries, he assumed that minority groups such as black Americans should feel obligated to assimilate and integrate into the dominant national community. Agreeing with Myrdal on this first point, some present-day Americans urge that the national American community is defined by a shared English language and 'American culture' more broadly. From their perspective, minority groups should feel obligated to shed their language, culture and customs in favour of the dominant white American ones. Like these Americans, many Swedes seem to believe that their national community is defined by particular values and culture and ask newcomers to adapt, assimilate and integrate into these mainstream norms. But for contemporaries who value multiculturalism, equality cannot require minority groups to make such a steep sacrifice. These modern-day debates jump off the pages when reading Gunnar Myrdal's An American Dilemma.

So too does Myrdal's discussion of American exceptionalism in race relations. Like him, many contemporaries still argue that the experience of white and black Americans is exceptional and distinct from other majority-minority relations in the US and abroad. This, however, might be more perception than reality. During the Second World War, Gunnar Myrdal needed white Americans to believe and make the rest of the 
world believe that their treatment of black Americans was unique. But as the Swedish roots to An American Dilemma suggest, white-black relations in the US might be less exceptional than Americans (and perhaps the rest of the world) might want to imagine.

\section{NOTES}

1. For feedback on this chapter, I thank the participants of Stockholm University's Demography Unit Seminar, in particular Vanessa Barker, Elizabeth Thomson, Sunnee Billingsley, Maria Branden and Jani Turunen. I am appreciative of the financial support of the Fulbright Commission and the American-Scandinavian Foundation, which made possible that 2011-12 academic year in Sweden. I also thank Anson Rabinbach, Hendrik Hartog, Stanley N. Katz and the editors of this volume for reading and commenting on drafts of this work. Of course, any and all errors and omissions are my own.

2. Frederick P. Keppel, 'Foreword', in Gunnar Myrdal, An American Dilemma: The Negro Problem and Modern Democracy (New York: Harper \& Brothers Publishers, 1944), vi.

3. Philip Henry Kerr and Lord Hailey, An African Survey: A Study of Problems Arising in Africa, South of the Sahara (London: Oxford University Press, 1938).

4. Memorandum, F. P. K. and Oldham, Subject: Int. Inst. of African Languages and Cultures, November 23, 1936, box 281, folder 281.1, Carnegie Corporation of New York Archives, Columbia University Rare Book and Manuscript Library (hereafter CCNYA).

5. Ibid. and Memorandum, 'Negro Study, Personnel Suggestions through July 15, 1937', microfilm roll no.1, Carnegie Corporation of New York Negro Study General Correspondence, CCNYA (hereafter CCNY NSGC).

6. Letter (translated summary), J. Th. Moll to H. Mouw, November 1936, microfilm roll no. 1, CCNY NSGC.

7. Ibid. and Memorandum, 'Negro Study'.

8. Letter, Donald Young to Frederick P. Keppel, January 39, 1937, microfilm roll no.1, CCNY NSGC.

9. Memorandum, 'Negro Study'.

10. Letter, Frederick P. Keppel to Gunnar Myrdal, August 18, 1937, microfilm roll no. 1, CCNY NSGC.

11. Letter, Gunnar Myrdal to Frederick P. Keppel, October 7, 1937, microfilm roll no. 1, CCNY NSGC.

12. See David M. Kennedy, Freedom From Fear: The American People in World War II (New York: Oxford University Press, 1999); Walter Jackson, Gunnar Myrdal and America's Conscience: Social Engineering and Racial Liberalism, 1938-1987 (Chapel Hill, NC: University of North Carolina Press, 1990); Ellen Condliffe Lagemann, The Politics of Knowledge: The Carnegie Corporation, Philanthropy, and Public Policy (Chicago: University of Chicago Press, 1989); Jerry Gershenhorn, Melville Herskovits and the Racial Politics of Knowledge (Lincoln, NE: University of Nebraska Press, 2004); and John P. Jackson, Social Scientists for Social Justice: Making the Case Against Segregation (New York: New York University Press, 2001).

13. Myrdal, An American Dilemma, xliii:

The American Negro problem is a problem in the heart of the American. It is there that the interracial tension has its focus. It is there that the decisive struggle goes on. This is the central viewpoint of this treatise. Though our study includes economic, social, and political race relations, at bottom our problem is the moral dilemma of the American the conflict between his moral valuations on various levels of consciousness and generality. The 'American Dilemma', referred to in the title of the book, is the ever-raging conflict between, on the one hand, the valuations preserved on the general plan which we shall call the 'American Creed', where the American thinks, talks, and 
acts under the influence of high national and Christian precepts, and, on the other hand, the valuations on specific plans of individual and group living, where personal and local interests; economic, social, and sexual jealousies; considerations of community prestige and conformity; group prejudice against particular persons or types of people; and all sorts of miscellaneous wants, impulses, and habits dominate his outlook.

14. See nn. 11-13.

15. Christian Fleck, A Transatlantic History of the Social Sciences: Robber Barons, the Third Reich and the Invention of Empirical Social Research (London: Bloomsbury Academic, 2011), ch. 3 'Institutional Support in Europe'; and Martin Bulmer and Joan Bulmer, 'Philanthropy and Social Science in the 1920s: Beardsley Ruml and the Laura Spelman Rockefeller Memorial, 1922-29', Minerva 19, 3 (September 1981).

16. See e.g. Gunnar Myrdal, Prisbildningsproblemet och föränderligheten (Uppsala, Sweden, 1927); Gunnar Myrdal, Vetenskap och politik i nationalekonomien (Stockholm: Norstedt, 1930); and Gunnar Myrdal, 'Folket och samhällsklasserna', 'Samhällsrörelser och organisationer' and 'Staten och ekonomiska livet' in Nils Herlitz, Svensk samhällslära (Stockholm: Svenska bokförlaget, 1929).

17. Yvonne Hirdman, Alva Myrdal: The Passionate Mind, translated by Linda Schenck (Bloomington: Indiana University Press, 2008), 147; and Allan Carlson, Swedish Experiment in Family Politics: The Myrdals and the Interwar Population Crisis (New Brunswick, NJ: Transaction Publishers, 1990), 42.

18. Carlson, Swedish Experiment, 45: 'In 1930, Gunnar Myrdal gave up his docentur at the University of Stockholm and accepted, at Cassel's urging, a better-paying, more prestigious position at the Institut universitaire de hautes Etudes Internationales in Geneva, teaching international economics.' A year later, he and Alva returned to Stockholm.

19. Hirdman, Alva Myrdal, 158, 201; Carlson, Swedish Experiment, 50; and Helen Rappaport, Encyclopedia of Women Social Reformers, vol. 1 (Santa Barbara, CA: ABC-CLIO, 2001), 472.

20. Alva Myrdal mentioned her and Gunnar's division of labour in the introduction to her 1941 book, Nation and Family: The Swedish Experiment in Democratic Family and Population Policy (New York: Harper \& Brothers Publishers, 1941), vii.

21. Alva and Gunnar Myrdal, Kris i befolkningsfrågan, (Stockholm: Bonniers, 1934), 'Inledning.'

22. For further discussion on the 'social corpus', see Anson Rabinbach, The Human Motor: Energy, Fatigue, and the Origins of Modernity (Berkeley, CA: University of California Press, 1990), chs 8 and 10.

23. See Mark Mazower, Dark Continent: Europe's Twentieth Century (New York: Vintage Books, 2000) (originally published, 1998), ch. 3 'Healthy Bodies, Sick Bodies'. Matthew Connelly, Fatal Misconception: The Struggle to Control World Population (Cambridge, MA: Harvard University Press, 2008), ch. 2 'To Inherit the Earth', 47:

After the Great War, the sense that the flower of a generation had been sacrificed for the mere yards of shell-blasted soil imparted an urgent lesson: the power and pride of nations were vested in their population, not territory, and governments must strive to increase their numbers or at least their 'quality'.

24. See Henrik Berggren and Lars Trägårdh, Är svensken människa?: Gemenskap och oberoende i det moderna Sverige (Stockholm: Norstedts, 2006), chapter 'Nationens barn, individens frihet'.

25. Myrdal, Kris, ch. 2, section 'Nativitet och inkomststandard'. Gunnar Myrdal began to distinguish his economic theories from those of earlier generations in his 1930 publication Vetenskap och politik $i$ nationalekonomien (Stockholm: P.A. Norstedt, 1930), later published in English as The Political Element in the Development of Economic Theory, translated by Paul Streeten (London: Routledge, 1953); see Carlson, Swedish Experiment, 38.

26. Myrdal, Kris, ch. 1 'Malthusianismen och nymalthusianismen'. 
27. Ibid., and see e.g. Jean H. Baker, Margaret Sanger: A Life of Passion (New York: Macmillan, 2011), 91.

28. Myrdal, Kris, ch. 2, section 'Nativitet och inkomstandard'.

29. Myrdal, Kris, ch. 3, section 'Tendenserna för den närmaste framtiden'. As pointed out in the literature on the Myrdals, they here captured an argument that was popular among the nationalistic right in Sweden (increasing fertility rates) and transformed it into an argument for social democratic economic and social policies. Such a capture of opponents' arguments was characteristic of the Myrdals. See e.g. Yvonne Hirdman, 'Crisis: The Road to Happiness', in Culture and Crisis: The Case of Germany and Sweden, (eds) Nina Witoszek and Lars Trägårdh (New York: Berghahn Books, 2002).

30. Myrdal, Kris, 9.

31. Ibid.

32. Bo Stråth, Sveriges Historia: 1830-1920 (Stockholm: Norstedts, 2009), 294. Notably, 97 per cent of Swedish emigrants went to the United States.

33. Myrdal, Kris, chs. 3, 7 and 8, section 'Den nya familjen'.

34. Myrdal, Kris, ch. 6, section 'Utjämning av barnförsörjningskostnaden genom socialpolitik'. For further discussion of the disputes among the Social Democrats and even Social Democratic women's organizations on mothers' ability to retain their employment outside their homes, see Hirdman, Alva Myrdal, 160-6.

35. Myrdal, Kris, ch. 6, section 'Utjämning av barnförsörjningskostnaden genom socialpolitik'.

36. Ibid. ch. 3, section 'Skola fruktsamhetstalen stanna i sitt fall och i så fall var?'

37. Ibid. ch. 2, section 'Rasbiologiska värdeskillnader mellan socialklasserna?'

38. Ibid.

39. Ibid. ch. 7, section 'Steriliseringsfrågan'.

40. Alberto Spektorowski and Elisabet Mizrachi, 'Eugenics and the Welfare State in Sweden: The Politics of Social Margins and the Idea of a Productive Society', Journal of Contemporary History, 39 (2004): 333-52, 347.

41. Ibid. See also Connelly, Fatal Misconception; and Alison Bashford and Philippa Levine, The Oxford Handbook of the History of Eugenics (New York: Oxford University Press, 2010).

42. Myrdal, Kris, ch. 2, section 'Rasbiologiska värdeskillnader mellan socialklasserna?'

43. Ibid.

44. Ibid.

45. Ibid.

46. Ibid.

47. Ibid.

48. Ibid. and ch. 7, section 'Steriliseringsfrågan'.

49. Myrdal, Kris, chap. 2, section 'Rasbiologiska värdeskillnader mellan socialklasserna?'

50. For a discussion of indigenous Sami and Jews in 1930s Sweden, see Hans-Ingvar Roth and Fredrik Hertzberg, Tolerance and Cultural Diversity in Sweden (San Domenico di Fiesole, Italy: European University Institute Press, 2010); Mikael Tossavainen, 'Jews in Sweden', in Encyclopedia of the Jewish Diaspora, vol. 3: Countries, Regions, and Communities, (ed.) M. Avrum Ehrlich (Santa Barbara, CA: ABC-CLIO, 2008), 1087-92.

51. Spektorowski and Mizrachi, 'Eugenics and the Welfare State in Sweden', 345, citing Herbert Tingsten, Den svenska socialdemokratiens idéutveckling, vol. 1 (Stockholm: Tidens Förlag, 1941), 336-8.

52. See e.g. Henrik Berggren and Lars Trägårdh, Är svensken människa? Gemenskap och oberoende I det moderna Sverige (Stockholm: Norstedts Förlag, 2006), 250. Some scholars have contested the relative influence of the Myrdals' Crisis in the Population Question on population policies in 1930s Sweden; see e.g. Bo Rothstein, The Social Democratic State: The Swedish Model and the Bureaucratic Problem (Pittsburgh, PA: University of Pittsburgh Press, 1998).

53. Hirdman, Alva Myrdal, 203.

54. Ibid., 210. 
55. Letter, Frederick P. Keppel to Raymond Fosdick, 1938, microfilm roll no. 1, CCNY NSGC.

56. Letter, Gunnar Myrdal to Frederick P. Keppel, January 28, 1939, series 1, sub-series 1.2, box 270, folder 2790, General Education Board Papers, Rockefeller Archive Center.

57. Ibid., 20.

58. Ibid. (underlining appears in original).

59. Ibid.

60. Myrdal, An American Dilemma, xi.

61. Letter (emphasis in original), Gunnar Myrdal to Frederick P. Keppel, May 8, 1939, microfilm roll no.1, CCNY GCNS.

62. Myrdal, American Dilemma, 'Author's Preface' and ch. 4 'Racial Beliefs'.

63. For example, ch. 9, 'Economic Inequality'; ch. 17, 'The Mechanics of Economic Discrimination as a Practical Problem'; ch. 18, 'Pre-War Labor Market Controls and Their Consequences for the Negro'; ch. 22, 'Political Practices Today'; ch. 24, 'Inequality of Justice'; ch. 28, 'The Basis of Social Inequality'. In these pages, he made use of Charles S. Johnson, Edwin R. Embree and Will Winton Alexander's The Collapse of Cotton Tenancy (Chapel Hill, NC: University of North Carolina Press, 1935); Richard A. Lester's Economics of Labor (Seattle: The Washington Book Store, 1940); Paul Lewinson's Race, Class and Party (New York: Oxford University Press, 1932); Marian D. Irish, 'The Southern One-Party System and National Politics', Journal of Politics 4 (1942), 80-94; Charles S. Magnum, Jr, The Legal Status of the Negro (Chapel Hill, NC: University of North Carolina Press, 1940); Allison Davis, Burleigh B. Gardner and Mary R. Gardner, Deep South: A Social Anthropological Study of Caste and Class (Chicago, IL: University of Chicago Press, 1941); W. E. B. DuBois, The Philadelphia Negro: A Social Study (Philadelphia, PA: University of Pennsylvania Press, 1899); W. E. B. DuBois, The Souls of Black Folk: Essays and Sketches (Chicago, IL: A.C. McClurg \& Co., 1903); W. E. B. DuBois, Black Reconstruction: An Essay toward a History of the Part which Black Folk Played in the Attempt to Reconstruct Democracy in America, 1860-1880 (New York: Harcourt, Brace and Co., 1935); W. E. B. DuBois, Dusk at Dawn: An Essay toward an Autobiography of a Race Concept (New York: Harcourt, Brace and Co., 1940); the Chicago Commission on Race Relations, The Negro in Chicago (Chicago, IL: University of Chicago Press, 1922); Henry Hill Collins, Jr, America's Own Refugees: Our 4,000,000 Homeless Migrants (Princeton, NJ: Princeton University Press, 1941); James Weldon Johnson, Along This Way: The Biography of James Weldon Johnson (New York: Viking Press, 1933); Robert Ezra Park and Ernest W. Burgess, Introduction to the Science of Sociology (Chicago, IL: University of Chicago Press, 1921); and memoranda prepared for Gunnar Myrdal by Ralph Bunche and Charles S. Johnson: 'The Political Status of the Negro' and 'Patterns of Negro Segregation' respectively. A draft of Ralph Bunche's memorandum is available in the Ralph Bunche Papers, 1927-1971, UCLA Special Collections, Box 38 Folder 7 to Box 40 Folder 6; and in the Ralph Bunche Papers, 1922-1988, Schomburg Center for Research in Black Culture of the New York Public Library, Box 31 Folder 2. A version of Bunche's memorandum was published years later under the title The Political Status of the Negro in the Age of FDR (Chicago, IL: University of Chicago Press, 1973); and Johnson's in his Patterns of Negro Segregation (New York: Harper \& Brothers, 1943).

64. Myrdal, American Dilemma, 928: 'In practically all its divergences, American Negro culture is not something independent of general American culture. It is a distorted development, or a pathological condition, of the general American culture.'

65. Ibid., 929.

66. Ibid., 966.

67. See e.g. Stephen Graubard, 'An American Dilemma Revisited', in An American Dilemma Revisited: Race Relations in a Changing World, (ed.) Obie Clayton (New York: Russell Sage Foundation, 1996), 9-10; Herbert Aptheker, The Negro People in America: A Critique of Gunnar Myrdal's An American Dilemma (New York: International Publishers, 1946); Ralph Ellison, 'An American Dilemma: A Review' in The Death of White 
Sociology: Essays on Race and Culture, (ed.) Joyce A. Ladner (New York: Random House, 1973), 81-95. In his review, Ellison wrote: 'Much of Negro culture might be negative, but there is also much of great value and richness, which, because it has been secreted by living and has made their lives more meaningful, Negroes will not willingly disregard ... In Negro culture there is much of value for America as a whole. What is needed are Negroes to take it and create of it "the uncreated consciousness of their race." In doing so they will do far more; they will help create a more human American.'

68. Myrdal, An American Dilemma, 929; Myrdal, Kris i befolkningsfrågan, 76.

69. Hirdman, Alva Myrdal, 221.

70. Ibid., 223.

71. Gunnar and Alva Myrdal, Kontakt med Amerika (Stockholm: A. Bonnier, 1941).

72. Hirdman, Alva Myrdal, 222-3; and Alva Myrdal's Memorandum, 'Notes on journey US 1940-43', vol.: 1.1: 008, Alva och Gunnar Myrdals Arkiv, Personliga handlingar, Alva Myrdal, Arbetarrörelsens Arkiv och Bibliotek, Stockholm.

73. See, Myrdal, Kontakt med Amerika; David M. Kennedy, Freedom from Fear: The American People in World War II (New York: Oxford University Press, 1999), ch. 1, 'The Agony of Neutrality'.

74. Myrdal, Kontakt, 32-3.

75. Ibid., 33.

76. Ibid., 34 .

77. Ibid., 51.

78. Ibid., 52.

79. Ibid.

80. Ibid.

81. Ibid., 56.

82. Hirdman, Alva Myrdal, 225.

83. Myrdal, American Dilemma, xliii.

84. Ibid., 24.

85. Ibid. 